Krauskopff, Gisèle and Pamela D. Mayer, 2000. The Kings of Nepal and the Tharu of the Tarai. Kirtipur: Research Centre for Nepal and Asian Studies (CNAS).

Krauskopff, Gisèle, 1999. Corvees in Dang: Ethno-Historical Notes, Pp. 47-62, In Harald O. Skar et. al. (eds.), Nepal: Tharu and Tarai Neighbours. Kathmandu: EMR.

Lowe, Peter, 2001. Kamaiya: Slavery and Freedom in Nepal. Kathmandu: Mandala Book Point in Association with Danish Association for International Cooperation (MS Nepal).

Müller-Böker, Ulrike, 1999. The Chitwan Tharus in Southern Nepal: An Ethnoecological Approach. Franz Stiner Verlag Stuttgart.

$\varnothing$ degaard, Sigrun Eide, 1999. Base and the Role of NGO in the Process of Local and Regional Change, Pp. 63-84, In Harald O. Skar (ed.), Nepal: Tharu and Tarai Neighbours. Kathmandu: EMR.

Rankin, Katharine, 1999. Kamaiya Practices in Western Nepal: Perspectives on Debt Bondage, Pp. 27-46, In Harald O. Skar (ed.), Nepal: Tharu and Tarai Neighbours. Kathmandu: EMR.

Regmi, M.C., 1978. Land Tenure and Taxation in Nepal. Kathmandu: Ratna Pustak.

Robertson, Adam, and Shisham Mishra, 199. Forced to Plough: Bonded Labour in Nepal's Agricultural Economy. London and Kathmandu: Anti-Slavery International and INSEC.

Sachau, E.C., 1888. Alberuni's India. London: Trubner and Co.

Sharma, Shiva and Manasa Thakurathi, 1998. A Revisit to the Kamaiya System of Nepal. Kathmandu: INSEC, Nepal.

Skar, Harald O., 1999. Becoming Rana: Identity and Regional SelfAscription in Lowland Nepal, In Harald O. Skar (ed.), Nepal: Tharu and Tarai Neighbours. Kathmandu: EMR.

Skar, Harald O., et. al. (eds.), 1999. Nepal: Tharu and Tarai Neighbours. Kathmandu: EMR.

\section{NEPALESE BUDDHISTS' VIEW OF HINDUISM ${ }^{1}$}

\section{Krishna B. Bhattachan}

\section{Introduction}

Nepal is a multi-caste/ethnic, multi-lingual, multi-cultural and multi-religious country. The Hindu "high castes" belong to Caucasoid race and they are divided into Bahun/Brahmin, Chhetri/ Kshatriya, Vaisya and Sudra/Dalits and the peoples belonging to the Hill castes speak Nepali and the Madhesi castes speak various mother tongues belonging to the same Indo-Aryan families. There are 59 indigenous nationalities of Nepal and most of them belong to Mongoloid race and speak Tibeto-Burman languages. There are Dravid and Proto-Australoid races, who speak Dravid and Munda language respectively and they are also Indigenous Nationalities of Nepal. About 125 languages and dialects belong to four language families, namely, Indo-Aryan, Tibeto-Burman, Dravid and Munda.

Nepalese peoples have faith in different religions, including animism, Bon, Kirata, Buddhism, Hinduism, Islam, Christianity, Jainism, Sikhism and Bahai (cf. Dastider 1995). All religions are divided into different sects. For example, Bon is divided into White Stripe Bon and Black Stripe Bon. Kirata is divided into White Stripe and Red Stripe Kirata and the followers of Guru Falgunanda. Similarly, Buddhism is divided into Hinayan. Mahayan, Bajrayan and Therbada (cf. Gurung 1987). Hinduism is divided into Shaivism, Vaisnavism etc. ${ }^{2}$ Similarly, Christians are divided into 
Protestants, Roman Catholics etc. Islam is divided into Shiya and Sunni groups. According to the census of 2001, Hindus comprise $80.6 \%$, Buddhists $10.7 \%$, Islam $4.2 \%$, Kirant 3.6\%, Christian $3.6 \%$ of the total $22,736,934$ population of Nepal (Table 1). The population of Jain and Sikh are less than 5,000. Non-Hindus have often expressed through different media that they have serious concern about reliability of census data on religion collected since the Census of $1952 / 54$. The exclusionary process adopted by the Hindu rulers in all the Census have resulted in an engineered data on religion that over-inflates Hindu population to somewhere between $80 \%$ to $90 \%$ and under-enumeration of non-Hindus, including Buddhists and Christians (cf. Bhattachan 2001; Gurung, 2002).

Table 1. Population by religion in the Census of 1952/54, 1991 and 2001

\begin{tabular}{|c|c|c|c|c|c|c|c|c|}
\hline Religion & $1952 / 54$ & $\%$ & 1991 & $\%$ & 2001 & $\%$ & $\begin{array}{r}\text { Increase-Decre } \\
1991-2001\end{array}$ & ase \\
\hline Hindu & $7,138,392$ & 88.8 & $15,996,953$ & 86.5 & $18,330,121$ & 80.6 & $2,333,168$ & 14.6 \\
\hline Buddhists & 707,104 & 8.6 & $1,439,142$ & 7.8 & $2,442,520$ & 10.7 & $1,003,378$ & 69.7 \\
\hline Islam & 208,899 & 2.6 & 653,218 & 3.5 & 954,023 & 4.2 & 300,805 & 46.0 \\
\hline Kirant & - & - & 318,389 & 1.0 & 818,106 & 3.6 & 499,717 & 157.0 \\
\hline Christian & - & - & 31,280 & 0.2 & 101,976 & 0.5 & 70,696 & 226.0 \\
\hline Jain & - & - & 7,561 & 0.0 & 4,108 & 0.0 & $-3,453$ & -45.7 \\
\hline Sikh & - & - & 9,292 & 0.1 & 5,890 & 0.0 & $-3,402$ & -36.6 \\
\hline Other & 6,840 & 0.0 & 17,124 & 0.1 & 86,080 & 0.4 & 68,956 & 402.7 \\
\hline Unidentifie & - & - & 18,138 & 0.1 & - & 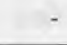 & - & \\
\hline Total & $8,235,079$ & 100 & 491,097 & 100 & $22,736,934$ & 100 & $4,245,887$ & 23.0 \\
\hline
\end{tabular}

Source: Table Number 10: Population by religion (cf. Gurung 2002:9).

His Majesty's Government of Nepal has recognized 59 Indigenous Peoples in Nepal and most of them belong to Mongolian race and speak Tibeto-Burman languages. However, the Constitution of the Kingdom of Nepal, 1990 promulgated after the downfall of the autocratic partyless Panchayat political system in 1990, which is modeled after West-Minister style of parliamentary form of government and where winner takes it all, have yet to recognize Nepal as a multi-religious country. Despite of strong demands for secularism, the Constitution declared Nepal as a Hindu state.

\section{Religious Conflict in Nepal}

Religious conflict is ubiquitous in the South Asia and Nepal is not exception to it (cf. Allen, 1993). Hindus are the dominant religious groups in Nepal. They, therefore, are in direct conflict with other religious groups, including Buddhist, Animist, Bon, Kirata, Islam and Christian. All non-Hindus are against Hinduism as the State religion- Hindu, political recognition of the Siva Sena ("Army of the Lord Shiva") as a registered political party, direct or indirect harassment against non-Hindus, particularly Christians and Islam, and engineered census data. ${ }^{3}$ Non-Hindus are for religious harmony, secularism, constitutional and legal equality, affirmative action or positive discrimination and true census data.

Almost all political leaders, planners, policy makers and development workers belong to the dominant caste, that is, the Hill BahunChhetris, they continue to engage in impression management that religious harmony is the characteristic of the Nepalese society since time immemorial. I attempted to deconstruct this myth by arguing that there has been no case of religious harmony in the past and present. David N. Geller has conceded that "religious harmony" has been exaggerated but he still does not agree that there is a serious religious conflict in Nepal (Gellner 1997: 6). It is true that Nepal has never experienced serious violent conflict but flashes of violence has occurred in the name of religion but such conflicts has been immediately suppressed by the local administration controlled by the dominant caste groups taking side of the perpetrators belonging to their own group. The latest clash was reported in the 
second week of August of 2002 between Hindus and Muslims in a village in the Mahottari district in the Terai region of central Nepal bordered with India and the local administration and political parties, which are dominated by the Hindus, suppressed it.

\section{Buddhists View of Hinduism ${ }^{4}$}

All Nepalese Buddhists have identical views about Hinduism though some may list more and others less about the differences between Buddhism and Hinduism or what Buddhists do and what Hindus do. What is interesting here is that Gautam Buddha was born in Nepal but he received Budhatwa ("enlightenment") in India and the Indian rulers like Ashoka was instrumental in spreading Buddhism around the region and the world. In contrast, Hinduism originated in India but by now Nepal has become the first Hindu country in the world. Thus, encroachment of Hinduism in Nepal and its dominant status for the last few centuries have often developed some tension between the Nepalese Buddhists and Hindus.

Given a long historical experience of overt and covert conflict between Buddhists and Hindus and the current political economic conditions, it is very natural that both Buddhists and Hindus have developed predominantly, following J. D. Gort, "prescriptive mode" or "negative theories, perceptions, attitudes and practices" against one another (Gort n.d.: 3). The distance between Buddhists and Hindus has widened after the heightened conflict between the Nepalese Buddhists and Hindus when the Hindus made a failed attempt to organize a Hindu-Buddhist Unity Conference inside the sacred Lumbini complex from November 19 to 21, 1999. Jayaendra Saraswati Shankacharya Kanchikamakoti and Goenka released a press statement from Varanassi, India stating that Hinduism and Buddhism are separate religions and that Buddha is not the ninth incarnation of Lord Vishnu as claimed by some Hindus and eventually it helped to diffuse the mounting tension. Due to strong protest from the Buddhists, the conference was organized in Siddharthanagar, a nearby town near Lumbini. Thus, direct physical conflict was averted but the psychological conflict continues. Later, Jayaendra Saraswati Shankacharya Kanchikamakoti, inaugurating the first World Hindu-Buddhist Conference in Lumbini, in Nepal 'said, "There is no difference between Hinduism and Buddhism" (Quoted by SPOTLIGHT 1999). The Nepalese Buddhists, on the contrary, views Buddhism different from Hinduism in many ways.

\section{Buddhists Views on Hindu Doctrines}

The Nepalese Buddhists believe that the doctrines of Hinduism and Buddhism are diametrically opposed (cf. Guvaju, 1990).

\section{Creation of God and Absolute Truth}

Hindus believe that god has created everything, including the Vedas. All Hindus regard four Vedas - the Rigveda, the Samveda, the Yajurveda and the Atharvaveda-as their supreme, holy and consensual documents created by gods. Also, they believe that it was true in the past, it is true at present and it will be true in future and they consider those people as Nastik ("atheist") who show disregard to the Vedas. Also, Hindus believe that priests are the mediators between god and human beings and thus, if Hindus satisfy their priests by giving money, commodities etc. ultimately gods will be satisfied.

The Nepalese Buddhists criticize such beliefs saying that these Vedas are neither the creation of god nor these are true forever. As Buddhists do not believe in the existence of any god they reject the divine authority of the Vedas. Following the Law of Dependent Origination ("Pratitya Samutpada") propounded by Budhha, Buddhists believe in cause and effect relationship but not on the divine origin (cf. Wadia, 1992). They, therefore, believe that priests are nothing but the "cheaters." 


\section{Hierarchy/purity and pollution of castes and foods}

Buddhists believe that hierarchy and purity and pollution of castes and foods are one of the worst characteristics of Hinduism. Hindu thoughts and practices are based on the paradigm of hierarchy, that is, everything is graded in a hierarchy, some are at the top, some are at the bottom and rest are in between. Hindus divide the society into fourfold Varna system, that is, Brahmins at the top followed by Kshyatriays and Vaishya and Sudra at the bottom of the hierarchy. Brahmans are considered superior and Sudras as the inferior, polluted or untouchables.

Nepalese Buddhists believe that is "upper caste" Hindus' strategy to perpetuates discriminatory caste system and discriminatory division of labor through the four-fold Varna hierarchy. Buddhists, therefore, believe that Hindus are naïve to say that the four Varnas were born out of different parts of the body of god Brahma ("god of creation")-Brahmin form his mouth, Kshyatriyas from his hand, Vaishya from his belly and Sudras from his feet. Also, Hindus believe that Brahmins' main duty is intellectual activities, Kshyatriyas' is security, Vaishyas' is economic activities and Sudras' is menial activities. The Varna system, therefore, is based on ascription and each individual's position in the Varna hierarchy is predestined; it cannot be changed through achievement.

\section{Atma ("Soul") and Its Rebirth}

Hindus strongly believe in the existence of Atma ("soul"). They believe that soul is eternal. Hindus believe in what Lord Krishna had said in the Bhagvad Gita ${ }^{5}$ that souls are like bodies and that soul may change its "bodies" just like we change new clothes or outfit if it should be old. Hindus believe that bodies are made of five elements-air, water, fire, earth and sky. They believe that bodies go through a series of birth and death and that even after death, soul may roam freely and harm people if they are satisfied. Hindus believe that if any individual should perform his/her "dharma" ("duty") in this life as sincerely as possible, his/her next life would be just wonderful and prosperous. Nepalese Buddhists do not agree with such Hindu beliefs about the existence of "soul" and its re-birth.

\section{Iswarbadi ("Belief in God")}

Buddha never believed in the existence of god or supernatural things. He did not believe in the creation of the world by gods. Instead, he explained the existence of living beings and things through cause and effect relationship. Hindus, on the contrary, believe in the existence of $33 \mathrm{Koti}$ gods and goddesses. Hindus believe that there is a presence of super mundane god (Vishnu) and the total number of gods is 33 Koti (330 million). Although, they regard Lord Brahma, Lord Vishnu and Lord Maheswor or Mahadev as the gods of creation, procreation and destruction respectively, they, in their every-day-life, worship powerful female goddesses such as Durga and Kali. What is interesting about Hindus is that they worship almost everything, including dogs. Hindus worship dog during the Tihar or Tyohar festival (the festival of lights) but do not hesitate to beat and kill dogs for next 364 days. Also, Hindus worship the most "powerful" gods and goddesses only and ignore other less powerful ones. For example, majority of Hindus visit temples of Lord Mahadev or Biswanath, Durga, Kali and Sankatmochan ("end crisis") than Brahma.

\section{Niskama Karma ("Work with no expectation of its fruits") or Fatalism}

Hindus care very little about this life but they are very much concerned about next lives. They say that all individuals should obediently and sincerely follow their dharma, including the dharma 
of varna and castes. If each and every individual does so in this life, his/her next life would be much better and prosperous. On the contrary, if they disobey, their next lives would be ruined. Sociologists and anthropologists characterize such a belief as fatalism. This means, Brhaman, Kshyatriya, Vaisahya and Sudra should perform their respective dharma. As this has been a social reality for several millenniums, "low castes" peoples have always been exploited and forced to remain in their "lowest" social status all the time. Thus, such a belief has positive impact on "high castes" and negative impacts on "low castes."

The Nepalese Buddhists criticize Hindus' such beliefs. Buddhists, on the contrary, believe that this life is more important and each and every individual who wish to get rid from sorrow and attain Nirvana, they must accept the four-fold truth and eight-fold path and follow Shila sincerely. It should be noted here that the Tibetan Buddhists believe that there is re-incarnation of Lamas. Such belief appears to be the influence of Hinduism.

\section{Conformity in means, not ends}

Hindus often try to justify means without relating them with ends. In the Bhagvada Gita, Lord Krishna suggested Arjun to act without expecting its fruits or outcomes. Thus, Hindus justify war, violence, exploitation etc. on this ground. On the contrary, Nepalese Buddhists, following the teachings of Buddha, believe that both cause and effect are interconnected. They believe that what one does has its definite outcome and whatever outcome one may see has its cause. For Buddhists, there is indeed no cause without effect and no effect without any cause.

\section{Intolerance}

Nepalese Buddhists strongly believe that Hindus are very intolerant with other religious groups. They do not hesitate to use the four policies, namely, Sam ("policy"), Dam ("Money or Gift"), Danda ("Punishment") and Bhed ("Divide"), developed by the famous scholar Chanakya. In the past, Nepalese Hindus' intolerance was exhibited in the form of burning of Buddhists texts, dismantling of Buddhists "bihars," "stupas," and "gombas" ("monasteries") and proseylitization in Hinduism by misusing State power and authority. At present Hindus' intolerance towards Buddhists (and also to Christians, Islams and other religious groups) is exhibited through political domination in executive, legislative, judiciary, media and political parties. For example, the Supreme Court of Nepal, in its verdict of August 17, 2002, did not find any evidence that the United Mission to Nepal (UMN) and ADRA-Nepal had engaged in proseylitization as alleged; nevertheless, the Court issued a directive order to the government to take strong action against those people or organizations who engage in proseylitization of the Hindus.

\section{Individualism}

The Nepalese Buddhists perceive that Hindus are primarily individualist. On the contrary, Buddhists are very much collectivists. Lord Buddha himself have emphasized on Sangha as one of the three shilas the praying Buddham Saranam Gachami, Dhamam sharanam gachhami and Sangham sarnam ghachami.

\section{Violence}

Buddhists believe that Hinduism is characterized by violence. Most of the powerful gods and goddesses, such as Shiva, Durga and Kali, symbolize violence. Many Hindus observe different types of sacrifice rituals including Pancha Bali ("five sacrifices"). The famous epics, namely, the Ramayan and the Mahabharat, are full of violence. Dasain is the biggest festival of the Nepalese Hindus and the offices of His Majesty's Government of Nepal are closed for 
about a week and educational institutions are closed for a month to celebrate the festival. On the eight and ninth day of the Dasain festivals, most of the Nepalese Hindus sacrifice animals such as goat, water buffalos, rooster, ducks, etc. in their homes. The Nepalese Buddhists have demanded with the government that killing of animals should be prohibited at least on the annual Buddha Jayanti, a day to celebrate Buddha, but they have turned a deaf ear so far. Buddhism, in contrast to Hinduism, is characterized by non-violence and peace.

\section{Extreme Paths}

Hindus are often said to be taking extreme paths. For example, there Hindus who believe in violence and there are other Hindus who believe in non-violence. Buddhists, on the contrary, follow the middle path.

\section{No Shila and No Liberation}

The Nepalese Buddhists appreciate Hindus' ideal behaviors. They believe that such ideals are pretensions because Hindus do not indeed practice it sincerely. The Nepalese Buddhists believe that liberation can be attained only through following shila and accepting four noble truth and the noble eight fold path. The four noble truth are (1) there is suffering in this world, (2) there are causes of suffering, (3) there are ways to do away with suffering, and (4) the ways to prevent suffering are this world itself. The noble eight fold path are (1) right view, (2) right thinking, (3) right speech, (4) right action, (5) right livelihood, (6) right diligence, (7) right mindfulness, and (8) right concentration.

\section{Buddhists views of Hindus' Politics of Religion}

The Nepalese Buddhists express their dismay about the "dirty" politics played by the Nepalese Hindus. Often, they mislead people and annoy Buddhists by spreading rumors that Buddhism is one of the branches of Hinduism. The following are the main issues of Hindu-Buddhist conflict.

\section{Omkar Family?}

The letter ${ }^{\circ}$ ("OM") has a great significance in Hinduism. Some Hindus argue that the Buddhists chant "Om Mani Padme Hun," they belong to the "Omkar" family, suggesting that Buddhism is a branch of Hinduism. There is no mention of the letter ॐ ("OM") in Buddhist texts such as Tripitak and Buddha never mentioned any significance of ॐँ (“OM").

\section{Buddha as the Ninth Incarnation of Lord Vishnu}

Hindus believe in 10 avatars ("incarnations") of Lord Vishnu. These are: (1) Matsya ("Fish") Avatar, (2) Kurma (Turtle) Avatar, (3) Baraha ("Pig") Avatar, (4) Narisingha ("Human body with Lion's head") Avatar, (5) Baman ("Dwarf") Avatar, (6) Parshuram Avatar, (7) Sriram Avatar, (8) Krishna Avatar, (9) Buddha Avatar, and (10) Kalki Avatar. Based on this belief, Hindus argue that Buddhism is a branch of Hinduism. In a book entitled Radio Style Book published by the government owned Radio Nepal, the authors have mentioned that "Hindus regard Buddha is regarded as the ninth incarnation of Vishnu" (Acharya et al. 2000:374). Every year, the newsreaders mention this statement by offending the sentiments of the Buddhists listeners. Buddhists take such a Hindu view very offensive. Buddhists defend it by saying that Buddha was very much against re-birth and gods. Instead, Buddha believed in Hetu Pratyaya, which means cause-effect relationship.

\section{State Patronization}

The Nepalese Hindus believe that Nepal should be a Hindu State, the King must be a descendent of Arya race and Hindu religion. 
Nepalese Buddhists do not agree with their first argument and have no objection on the second one. They argue that State like the Nepalese State can have no religion of its own because Nepal is a multi-religious, multi-caste and ethnic, multi-lingual and multicultural society. Buddhists along with other non-Hindu religions such as Bon, Kirata, Animism, Christianity and Islam have demanded that the Constitution should declare Nepal a secular country.

\section{Closed (Proselytization as a threat) membership}

Buddhists believe that Hinduism is a closed system where people with faith in other religions cannot become Hindus. On the contrary, there is no such restriction in Buddhism. In Hindu society, Varna and caste hierarchy is based on ascription. Therefore, people at the top generally do not fall down, except in violation of caste rules such as marriage relationship with "low castes". "Low caste" people have no chance to move up in the caste hierarchy, though few of them move up through the process of Sanskritization. Many Dalits ("low castes") in Nepal strongly believe that they can not get be free from caste-based discrimination as long as they follow Hinduism. Many of them, therefore, aspire to adopt Christianity or Buddhism. The Buddhists of Nepal have no problem in accepting them but the Hindus do not accept Buddhists or Christians or Islams turned into Hindus.

\section{Cold Approach towards the Development of Lumbini}

After the visit of U Thant, UN Secretary General from Burma, in Lumbini in Nepal in 1967, he appealed the international community to contribute for the development of Lumbini. Accordingly, Japanese archaeologist Prof. Kenzo Tange prepared the Lumbini Master Plan in 1978 for the development of Lumbini in 1150 bighas of land divided into three zones: (1) garden, (2) monasteries, and (3) research center. Unfortunately, Lumbini's development is moving in a snails pace because of cold attitude of His Majesty's Government of Nepal during the partyless Panchayat political system (1960-1990) and in the last twelve years after the reinstatement of democracy in 1990. The Nepalese Buddhists believe that the dominant Hindus, including rulers, planners, policy makers, decision makers, political leaders and intellectuals do not want to see the development of Lumbini and Buddhism (and also other non-Hindu religion, including Christianity).

\section{Hindus' disrespect to other religions}

The Nepalese Hindus believe that Hinduism is the only superreligion of the world and all other "religions," including Buddhism, Christianity and Islam, are its branches. In practice, however, the Nepalese Hindus have a lot of ill feelings against both Christians and Islam. The Nepalese Buddhists are of the views that the Nepalese Hindus wrongly suspect all international donors community as agents of proselytization of Hindus to Christianity and that all Islam are agents of ISI of Pakistan.

\section{Anti-non-Hindu stance of Hindu fundamentalist organizations}

The Nepalese Hindus have close ties with Hindu fundamentalists and extremists of India. For example, the Nepalese Hindus have established Shiva Sena ("Army of the Lord Shiva") in Nepal and registered with the Election Commission of Nepal of His Majesty's Government of Nepal as a political party. They have close link with the Shiva Sena of India lead by Mr. Bal Thakrey. Similarly, the Nepalese leaders of Biswa Hindu Mahasangh ("the World Federation of Hindus") also have close ties with the Bharatiya Janata Party (BJP), the ruling party of India. 


\section{Conclusion}

Nepal being a multi-religious country, religious tolerance and harmony is required for maintaining peace and attaining development. However, the first precondition for developing such harmony is that the Nepalese State should possess no religion. In other words, Nepal should be declared as a secular country. The second precondition is that the Nepalese Hindus should change their negative attitude and dominating behavior against non-Hindus, including the Buddhists. Hindus should indeed give up for good their wrong belief that Buddhism is a branch of Hinduism, that Buddha is the ninth incarnation of Lord Vishnu and that Buddhism is one the members of ("Omkar") family. Also, the census of 2011 should bring out true population of different religious groups. The Nepalese Buddhists believe that Buddhism is neither a religion nor an irrational faith but it is a process of becoming or a peaceful way of life or a science of living and looking at the world.

\section{End notes}

1. This is a revised version of my paper "Nepalese Buddhists' View of Hinduism" presented in an "International Interreligious Workshop: Religions View Religions: Explorations in Pursuit of Understanding"organized by the Research Group on The Encounter of religious Traditions, Faculty of Theology, Free University, Amsterdam, the Netherlands at the Retreat Centre, Guldenberg, Helvoirt, the Netherlands on November 1-4, 2002. I highly appreciate support and inputs provided by Prof. Hendrik M. Vroom and Prof. J. D. Gort, and Prof. Laurence Minnema of Free University of Amsterdam, and other participants of the workshop to enrich my paper.

2. According to Max Weber, "The term "Hindu" was first used under the foreign domination of the Mohammedans to mean unconverted native Indians. Only in recent literature have the Indians themselves begun to designate their religious affiliation as Hinduism" (Weber 1967: 4).
3. Johan Galtung writes, “...buddhism is not a question of sudden conversion, of becoming something one was not before, but of a process, of always becoming" (Galtung 1988: IX).

4. The Election Commission would not register political parties formed by the non-Hindus with similar explicit religious connotation such as the "Buddhist Army" or "Christian Army."

5. In the course of writing this paper, I talked to several Buddhist scholars, monks, activists, students and laypersons seeking their views about how they vie Hinduism. Also, I reviewed a couple of literature written by Nepalese Buddhist scholars. Also, I have developed some views on Hinduism from a sociological perspective and also from my own life experience as a Buddhist.

6. The Vagavad Gita for Hindus is like Bible for Christians and Kuran for Islams.

\section{References Cited}

Bhattachan, Krishna B.2001 "Buddhism and Social Harmony in Nepal," Pp. 92-101. Swarna-Smarika. Nagbahal, Lalitpur: Hiranyavarna Mahabihar. (Text in Nepali).

Dastider, Mollica1995 Religious Minorities in Nepal. New Delhi: Nirala Publications.

Douglas, Allen (Ed.) 1993 Religion and Political Conflict in South Asia. Delhi: Oxford University Press.

Galtung Johan 1988 Buddhism: A Quest for Unity and Peace, Honolulu: Dae Won Sa Buddhist Temple of Hawaii.

Gellner, David N.1997 "Ethnicity and Nationalism in the World's Only Hindu State." Pp.3-31. In: David N. Gellner, Joanna Pfaff Czarnecka \& John Whelpton (Eds.) Nationalism and Ethnicity in a Hindu Kingdom. The Politics of Culture in Contemporary Nepal. The Netherlands: Harwood Academic Press.

Gort, J. D.n.d. "Religions View Religions. A Brief definition of the Theme of an International Interreligious Workshop." Amsterdam: Free University of Amsterdam. 
Gurung, Harka1987 Himali Chhetrama Baudha Dharma ("Buddhism in Himalayan Region"). A paper presented in the first national Buddhist Conference in Kathmandu.

2001 Janaganana-2001 E. Anusar Jatiya Tathyanka Prambhik Lekhajokha ("Ethinc Data in accordance to the Cencus of 200I A.D.: Preliminary Assessment"). Kathmandu: Dharmodaya Sabha.

Guvaju, Tilak Man1990 Ke Buddhadharma Hindudharmako Sakha Ho Ra? ("Is Buddhism a Branch of Hinduism?"). Pokhara, Nepal: Sriprasad Tamu. (Text in Nepali).

Mukunda, Acharya et al.2000 Radio Style Book. Kathmandu: Radio Nepal.

SPOTLIGHT 1999 SPOTLIGHT. Vol. 19, Number 19, November 26December 2, 1999.

Wadia, A.S. 1992 The Message of Buddha. Delhi: Book Faith India. (First published in 1938).

Weber, Max 1967 The Religion of India. The Sociology of Hinduism and Buddhism. Translated and Edited by Hans H. Gerth and Don Martindale. New York: The Free Press, 1967

\section{CULTURE AND POLITICS OF CASTE IN THE HIMALAYAN KINGDOM}

Tulshi Ram Pandey

This paper defines the concept of caste as it can be derived from the literature and attempts to highlight the modality of its manifestations in the context of Nepal. It argues that caste as an ideology or a system of values should not be taken as a face value while it is judged in terms of its application in field reality. Evidences from its practice in Nepal do suggest that it is highly molded by the cultural context of society and political interest of the rulers. Many of its ideological elements apply only partially in field situations.

\section{Defining the Concept of Caste}

Indeed, the division of the population into a number of caste groups is one of the fundamental features of social structure in Hindu society. In these societies, one can encounter with different groups of people identified by a variety of caste names. Even in Nepal, the prevalence of such a division of the population is evident from the fact that the national census of 2001 presents demographic information for more than one hundred caste/ethnic groups. Caste division as a feature of Nepalese society can be discerned not only at its macro national level. Even in micro settings like individual villages, people are divided into a number of caste groups. Let us begin our discussion by settling the meaning of the concept of 